\title{
Small heterodimer partner (SHP) contributes to insulin resistance in cardiomyocytes
}

Citation for published version (APA):

Rodriguez-Calvo, R., Chanda, D., Oligschlaeger, Y., Miglianico, M., Coumans, W. A., Barroso, E., Tajes, M., Luiken, J. J. F. P., Glatz, J. F. C., Vazquez-Carrera, M., \& Neumann, D. (2017). Small heterodimer partner (SHP) contributes to insulin resistance in cardiomyocytes. Biochimica et Biophysica ActaMolecular and Cell Biology of Lipids, 1862(5), 541-551. https://doi.org/10.1016/j.bbalip.2017.02.006

Document status and date:

Published: 01/05/2017

DOI:

10.1016/j.bbalip.2017.02.006

Document Version:

Publisher's PDF, also known as Version of record

Document license:

Taverne

Please check the document version of this publication:

- A submitted manuscript is the version of the article upon submission and before peer-review. There can be important differences between the submitted version and the official published version of record.

People interested in the research are advised to contact the author for the final version of the publication, or visit the DOI to the publisher's website.

- The final author version and the galley proof are versions of the publication after peer review.

- The final published version features the final layout of the paper including the volume, issue and page numbers.

Link to publication

\footnotetext{
General rights rights.

- You may freely distribute the URL identifying the publication in the public portal. please follow below link for the End User Agreement:

www.umlib.nl/taverne-license

Take down policy

If you believe that this document breaches copyright please contact us at:

repository@maastrichtuniversity.nl

providing details and we will investigate your claim.
}

Copyright and moral rights for the publications made accessible in the public portal are retained by the authors and/or other copyright owners and it is a condition of accessing publications that users recognise and abide by the legal requirements associated with these

- Users may download and print one copy of any publication from the public portal for the purpose of private study or research.

- You may not further distribute the material or use it for any profit-making activity or commercial gain

If the publication is distributed under the terms of Article $25 \mathrm{fa}$ of the Dutch Copyright Act, indicated by the "Taverne" license above, 


\title{
Small heterodimer partner (SHP) contributes to insulin resistance in cardiomyocytes
}

\author{
Ricardo Rodríguez-Calvo a,*,1, Dipanjan Chanda ${ }^{\text {a }}$, Yvonne Oligschlaeger ${ }^{\mathrm{a}}$, Marie Miglianico a ${ }^{\mathrm{a}}$, Will A Coumans ${ }^{\mathrm{a}}$, \\ Emma Barroso ${ }^{\mathrm{b}}$, Marta Tajes ${ }^{\mathrm{c}}$, Joost JFP Luiken ${ }^{\mathrm{a}}$, Jan FC Glatz ${ }^{\mathrm{a}}$, \\ Manuel Vázquez-Carrera ${ }^{\mathrm{b}}$, Dietbert Neumann ${ }^{\mathrm{a}, *}$
}

a Department of Molecular Genetics, CARIM School for Cardiovascular Diseases, Faculty of Health, Medicine and Life Sciences, Maastricht University, 6200 MD Maastricht, Netherlands

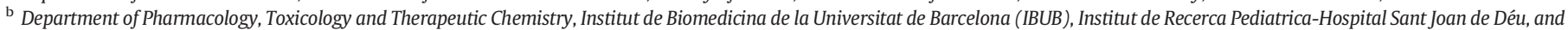

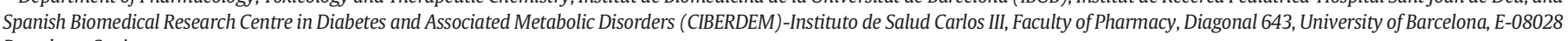
Barcelona, Spain

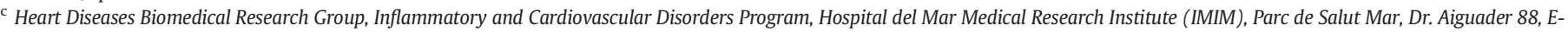
08003, Barcelona, Spain

\section{A R T I C L E I N F O}

\section{Article history:}

Received 22 September 2016

Received in revised form 18 January 2017

Accepted 13 February 2017

Available online 16 February 2017

\section{Keywords:}

Insulin resistance

Diabetic cardiomyopathy

Nuclear receptors

Small heterodimer partner

\begin{abstract}
A B S T R A C T
Small heterodimer partner (SHP) is an atypical nuclear receptor expressed in heart that has been shown to inhibit the hypertrophic response. Here, we assessed the role of SHP in cardiac metabolism and inflammation. Mice fed a high-fat diet (HFD) displayed glucose intolerance accompanied by increased cardiac mRNA levels of Shp. In HL-1 cardiomyocytes, SHP overexpression inhibited both basal and insulin-stimulated glucose uptake and impaired the insulin signalling pathway (evidenced by reduced AKT and AS160 phosphorylation), similar to insulin resistant cells generated by high palmitate/high insulin treatment (HP/HI; $500 \mu \mathrm{M} / 100 \mathrm{nM})$. In addition, SHP overexpression increased Socs 3 mRNA and reduced IRS-1 protein levels. SHP overexpression also induced Cd36 expression $(\sim 6.2$ fold; $\mathrm{p}<0.001)$ linking to the observed intramyocellular lipid accumulation. SHP overexpressing cells further showed altered expression of genes involved in lipid metabolism, i.e., Acaca, Acadvl or Ucp3, augmented NF- $k$ B DNA-binding activity and induced transcripts of inflammatory genes, i.e., Il6 and Tnf mRNA ( 4fold induction, $\mathrm{p}<0.01$ ). Alterations in metabolism and inflammation found in SHP overexpressing cells were associated with changes in the mRNA levels of Ppara (79\% reduction, $\mathrm{p}<0.001)$ and Pparg ( 58 -fold induction, $\mathrm{p}<0.001$ ). Finally, co-immunoprecipitation studies showed that SHP overexpression strongly reduced the physical interaction between PPAR $\alpha$ and the p65 subunit of NF-kB, suggesting that dissociation of these two proteins is one of the mechanisms by which SHP initiates the inflammatory response in cardiac cells. Overall, our results suggest that SHP upregulation upon high-fat feeding leads to lipid accumulation, insulin resistance and inflammation in cardiomyocytes.
\end{abstract}

(c) 2017 Elsevier B.V. All rights reserved.

Abbreviations: Acaca, acetyl-CoA carboxylase; Acadvl, acyl-CoA dehydrogenase, very long chain; Acot1, acyl-CoA thioesterase 1; Acox1, acyl-CoA oxidase 1; AS160, AKT substrate of

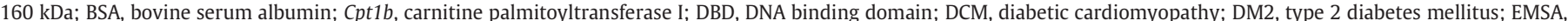

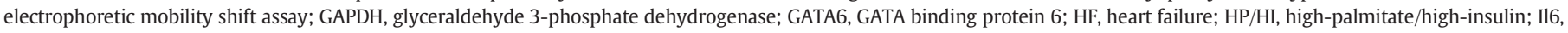

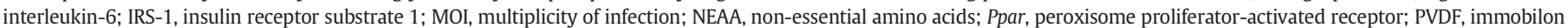

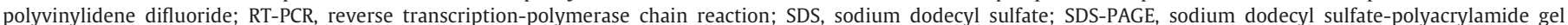

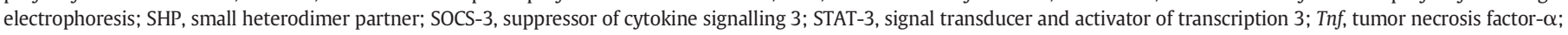
Ucp3, uncoupling protein-3.

* Corresponding authors.

E-mail addresses: rrodriguez080480@yahoo.es (R. Rodríguez-Calvo), d.neumann@maastrichtuniversity.nl (D. Neumann).

${ }^{1}$ Current address: Vascular Medicine and Metabolism Unit, Research Unit on Lipids and Atherosclerosis, Sant Joan University Hospital, Pere Virgili Health Research Institute (IISPV) and

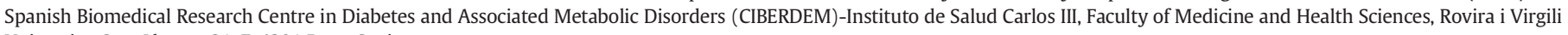
University, Sant Llorenç 21, E-4301 Reus, Spain. 


\section{Introduction}

Insulin resistance increases the risk for heart failure, the leading cause of death in subjects with type 2 diabetes (DM2) [1]. The underlying mechanisms involved in the pathogenesis of diabetic cardiomyopathy (DCM) include disturbances in myocardial energy metabolism and a chronic low-grade inflammatory process in cardiac tissue. Diabetic hearts are unresponsive to insulin-stimulation of glucose uptake, whereas (longchain) fatty acid uptake and utilization are increased. This greater fatty acid influx exceeds the mitochondrial $\beta$-oxidative capacity [2], leading to a gradual intramyocellular build-up of inert triacylglycerol stores and bioactive lipid metabolites (diacylglycerols, ceramides). The accumulation of these lipid intermediates in cardiomyocytes elicits insulin resistance, impairing both insulin-stimulated glucose uptake [3] and oxidation [4]. Furthermore, elevated concentrations of these lipid intermediates have been linked to NF- $\kappa$ B activation [5] and aberrant cytokine production, which may explain the putative link between the onset of chronic low-grade inflammation and metabolic disorders. Over time, both excessive lipid accumulation and progressive insulin resistance in combination with inflammatory processes will gradually initiate a remodelling process in the heart, which at first appears to be a compensatory adaptation, thereafter fostering the development of a functional impairment, i.e., heart failure $[1,6]$.

At the molecular level, nuclear receptors have emerged as relevant players in the regulation of gene expression profiles in metabolism and inflammation, not only acting as ligand-activated transcription factors, but also interfering with other gene expression regulators independent of their DNA-binding mechanisms. However, the role of nuclear receptors in the regulation of cardiac metabolism still remains partly uncharted. Small heterodimer partner (SHP) (NROB2, according to the unified nomenclature system for the nuclear receptors [7]) is an atypical nuclear receptor characterized by the lack of a DNA binding domain (DBD) [7]. SHP predominantly acts by regulating the activity of other transcription factors through a number of different mechanisms [8]. Several studies have suggested the possible involvement of SHP in peripheral insulin resistance (for review see [9]). In liver, SHP inhibits gluconeogenesis [10-15] and improves insulin sensitivity through the inhibition of the signal transducer and activator of transcription 3 (STAT-3), and the expression of suppressor of cytokine signalling 3 (SOCS-3) [16]. In the heart, SHP expression blocks cardiac hypertrophy by interfering with GATA binding protein 6 (GATA6) signalling [17]. Concerning the role of SHP in the regulation of the inflammatory response, conflicting results have been reported in different contexts, i.e., SHP exerts anti-inflammatory effects [18-20], and SHP takes part in NF- $\kappa B$ activation [21-24]. In particular, the role of this nuclear receptor in cardiac glucose/lipid metabolism and inflammation is understudied.

Here, we report that SHP mRNA levels in heart positively correlate with glucose intolerance in high-fat diet (HFD)-fed mice, and that SHP overexpression in HL-1 cardiomyocytes results in insulin resistance and upregulation of the inflammatory processes, which therefore mimics the cellular responses induced by high-palmitate/high-insulin (HP/HI) treatment.

\section{Material and methods}

\subsection{Reagents}

2-deoxy-D- $\left[{ }^{3} \mathrm{H}\right]$-deoxyglucose was obtained from GE Healthcare. Palmitate, insulin and bovine serum albumin (BSA) were purchased from Sigma.

\subsection{Animals}

Animal experiments were performed in a well-characterized model [25-27]. Five-week-old CD-1 male mice were maintained on a standard light-dark cycle (12 h light/dark cycle) and temperature $\left(21 \pm 1{ }^{\circ} \mathrm{C}\right)$ conditions, with ad libitum access to food and water. Animals were randomly distributed in two experimental groups $(\mathrm{n}=5$ each) and fed with a standard chow diet (STD; Harlan Ibérica S.A.) or a high-fat diet (HFD; 35\% fat by weight, 58\% kcal from fat; Harlan Ibérica S.A.) for 3 weeks. Before the end the procedure, a glucose tolerance test was performed on mice fasted for $4 \mathrm{~h}$. Briefly, animals received $2 \mathrm{~g} / \mathrm{kg}$ body weight of glucose by intraperitoneal injection, and blood was collected from the tail vein after $0,15,30,60$, and $120 \mathrm{~min}$. Area Under the Curve (AUC) was determined as a measure of glucose intolerance. After 3 weeks, mice were sacrificed under isoflurane anaesthesia and the hearts were immediately frozen in liquid nitrogen and then stored at $-80{ }^{\circ} \mathrm{C}$. These experiments conformed to the Guide for the Care and Use of Laboratory Animals published by the U.S. National Institutes of Health (NIH publication no. 85-23, revised 1996). All procedures were approved by the University of Barcelona Bioethics Committee, as stated in Law 5/21 July 1995 passed by the Generalitat de Catalunya (Autonomous Government of Catalonia).

\subsection{Cell culture}

HL-1 atrial cardiomyocytes were kindly provided by dr. W. Claycomb (Louisiana State University, New Orleans, LA, USA), and cultured in Claycomb medium (supplemented with 10\% FCS, $0.1 \mathrm{mmol} / \mathrm{l}$ noradrenaline [norepinephrine], $2 \mathrm{mmol} / \mathrm{l} \mathrm{L}$-glutamine, $100 \mathrm{U} / \mathrm{ml}$ penicillin and $100 \mu \mathrm{g} / \mathrm{ml}$ streptomycin). Rat cardiomyocytes were isolated using a Langendorff perfusion system, as previously described [28] and seeded in laminin coated plates. After 90 min adhesion in modified Krebs-Ringer medium [28], cells were cultured according to the method described by Volz et al. [29] in modified serum-free medium M199 supplemented with $5 \mathrm{mM}$ creatine monohydrate, $3.2 \mathrm{mM}$ carnitine hydrochloride, $3.1 \mathrm{mM}$ taurine, 100 units/ml penicillin and $10 \mathrm{mg} / \mathrm{ml}$ streptomycin. Both HL-1 cells and primary rat cardiomyocytes were maintained at $37^{\circ} \mathrm{C}$ and $5 \% \mathrm{CO}_{2}$. Cells were seeded in multi-well plates and transduced for $48 \mathrm{~h}$ with adenoviral particles at a multiplicity of infection (MOI) of 50, as previously described [14]. SHP over-expression was verified by real-time PCR. Alternatively, non-transduced cells were serum deprived in Dulbecco's Modified Eagle Medium (DMEM; supplemented with $2 \mathrm{mM}$ L-glutamine, $100 \mu \mathrm{M}$ non-essential amino acids (NEAA), $100 \mathrm{U} / \mathrm{ml}$ penicillin and $100 \mu \mathrm{g} / \mathrm{ml}$ streptomycin) for $24 \mathrm{~h}$, and then challenged with high palmitate $(500 \mu \mathrm{M}$, palmitate:BSA 3:1)/high insulin (100 nM) (HP/HI) for $16 \mathrm{~h}$.

HEK 293T (used to amplify and titrate adenovirus) were cultured in DMEM supplemented with 10\% FCS, 2 mM L-glutamine and antibiotics (100 $\mathrm{U} / \mathrm{ml}$ penicillin and $100 \mu \mathrm{g} / \mathrm{ml}$ streptomycin).

\subsection{Preparation of recombinant adenovirus}

For ectopic expression of SHP, adenoviral delivery system was used. Adenoviruses encoding Enhanced Green Fluorescence Protein (Ad), or the full-length human SHP (Ad-SHP), were kindly provided by Dr. Hueng-Sik Choi (Hormone Research Center, School of Biological Sciences and Technology, Chonnam National University, Gwangju) [10]. Large-scale amplification of adenovirus and viral titers were performed in HEK 293T cells. Briefly, cells were transduced with recombinant adenoviruses (Ad or Ad-SHP) and cells and supernatants were collected once cytopathic effect was observed. After three freeze and thaw cycles, cells debris were pelleted and supernatant containing adenoviral particles were used to determine the MOI by 10 -fold serial dilutions.

\subsection{Measurement of 2-deoxy-D-[3 H]-glucose uptake}

2-Deoxy-D- $\left[{ }^{3} \mathrm{H}\right]$-glucose uptake was measured as previously described $[30,31]$ in HL-1 cells transduced with adenoviral particles, or stimulated with $\mathrm{HP} / \mathrm{HI}$. Briefly, cells were washed with uptake-buffer (117 mM NaCl, $2.6 \mathrm{mM} \mathrm{KCl}, 1.2 \mathrm{mM} \mathrm{KH}_{2} \mathrm{PO}_{4}, 1.2 \mathrm{mM} \mathrm{MgSO}_{4}, 10 \mathrm{mM}$ $\mathrm{NaHCO}_{3}, 10 \mathrm{mM}$ HEPES, $1 \mathrm{mM} \mathrm{CaCl}$ ) containing $4.6 \mathrm{mg} / \mathrm{ml} \mathrm{BSA}$, and 
challenged with $200 \mathrm{nM}$ insulin for $30 \mathrm{~min}$. Subsequently, deoxy-D-glucose was added to a final concentration of $4 \mu \mathrm{M}$ with tracer amounts of 2-deoxy-D- $\left[{ }^{3} \mathrm{H}\right]$-glucose $(2.17 \mu \mathrm{Ci})$. After $10 \mathrm{~min}$, uptake was stopped with ice-cold stop-solution (uptake-buffer containing $1 \mathrm{mg} / \mathrm{ml} \mathrm{BSA}$, $0.2 \mathrm{mM}$ phloretin and $0.1 \%$ of DMSO). Then, cells were lysed with $1 \mathrm{M}$ $\mathrm{NaOH}$, and incorporated glucose was measured by scintillation counting of ${ }^{3} \mathrm{H}$ in a $\beta$-counter.

\subsection{Immunoblotting}

HL-1 cells transduced with adenoviral particles, or stimulated with $\mathrm{HP} / \mathrm{HI}$, were challenged with $200 \mathrm{nmol} / \mathrm{l}$ insulin for $30 \mathrm{~min}$. To obtain whole cellular extracts RIPA buffer (50 mM Tris-HCl, $150 \mathrm{mM} \mathrm{NaCl}, 1 \%$ Igepal, $0.5 \%$ Sodium deoxycholate, $0.1 \%$ sodium dodecyl dulfate (SDS) containing proteases and phosphatases inhibitors) was used. Protein concentration was measured by the BCA protein assay ${ }^{\mathrm{TM}}$ and equal amounts were resolved by sodium dodecyl sulfate-polyacrylamide gel electrophoresis (SDS-PAGE) and transferred to Immobilon polyvinylidene diflouride (PVDF) membranes. Western blot analyses were performed using antibodies against phospho-Ser ${ }^{473}$-AKT, AKT (Cell Signaling), phospho-Thr ${ }^{642}$-AS160 (AKT substrate of $160 \mathrm{kDa}$ ), AS160 (Upstate), Insulin receptor substrate 1 (IRS-1) (Cell Signaling), succinate dehydrogenase complex iron sulfur subunit B Complex II (CII-SDHB) (Abcam) and Glyceraldehyde 3-phosphate dehydrogenase (GAPDH) (Cell Signaling). Detection was performed using the appropriate horseradish peroxidase-labelled IgG and the Chemiluminescent Peroxidase Substrate-1 (Sigma). The size of detected proteins was estimated using protein molecular-mass standards (Thermo Scientific, Waltham, MA USA). Western blot images were analysed with a Molecular Imager (ChemiDoc XRS, BioRad) and quantified with Quantity One ${ }^{\circledR}$ (BioRad).

\subsection{Oil-Red-O staining}

Lipid content was measured in HL-1 transduced with adenoviral particles using the Oil-Red-O staining. Cells were fixed in ice-cold $4 \%$ paraformaldehyde for $15 \mathrm{~min}$ and stained with fresh Oil-Red-O (Sigma) solution for $30 \mathrm{~min}$. Nuclei were counterstained with Haematoxylin and cells were mounted with Faramount mounting medium (Dako) after extensive washing. Pictures were taken at $40 \times$ magnification with a Nikon digital camera DMX1200 and ACT-1 v2.63 software from Nikon Corporation. The lipid content was quantified by Image J software from five random fields of three different experiments.

\subsection{RNA preparation and quantitative real time reverse transcription-poly-} merase chain reaction ( $R T-P C R)$ analysis

Levels of mRNA were assessed by the real time RT-PCR as previously described [31]. Total RNA was isolated using the TRI Reagent (Sigma, Saint Louis, USA) according to the manufacturer's recommendations. RNA integrity was determined by electrophoresis in agarose gel. Total RNA $(1 \mu \mathrm{g})$ was reverse-transcribed using the iScript ${ }^{\mathrm{TM}}$ cDNA Synthesis Kit (BioRad). Levels of mRNA were assessed by real-time PCR on an ABI PRISM 7900 sequence detector (Applied Biosystems). Primers for SYBR Green real-time PCR analysis are listed in Table 1. Cyclophilin A was used as endogenous control.

\subsection{Mitochondrial inner membrane potential}

The mitochondrial inner membrane potential were determine using the reagent MitoTracker Red CMXRos (Invitrogen), following the manufacturer's instructions.
Table 1

Primers for SYBR Green real-time PCR.

\begin{tabular}{|c|c|}
\hline Gene & Sequences \\
\hline \multirow{2}{*}{ Shp } & Forward: 5'-TCCTCTTCAACCCAGATGTGC-3' \\
\hline & Reverse: 5'-TCTCCCATGATAGGGCGGAA-3' \\
\hline \multirow{2}{*}{ Pepck } & Forward: 5'-AAGCATTCAACGCCAGGTTC-3' \\
\hline & Reverse: 5'-GGGCGAGTCTGTCAGTTCAAT-3' \\
\hline \multirow{2}{*}{ G6p } & Forward: 5'-CGACTCGCTATCTCCAAGTGA-3' \\
\hline & Reverse: 5'-GTTGAACCAGTCTCCGACCA-3' \\
\hline \multirow{2}{*}{ Glut4 } & Forward: 5'-GCTTTGTGGCCTTCTTTGAG-3' \\
\hline & Reverse: 5'-CAGGAGGACGGCAAATAGAA-3' \\
\hline \multirow{2}{*}{ Pdk4 } & Forward: 5'-CACCACATGCTCTTCGAACTCT-3' \\
\hline & Reverse: 5'-AAGGAAGGACGGTTTTCTTGATG-3' \\
\hline \multirow{2}{*}{ Socs3 } & Forward: 5'-CCTTTCTTATCCGCGACAGC-3' \\
\hline & Reverse: 5'-CGCTCAACGTGAAGAAGTGG-3' \\
\hline \multirow{2}{*}{ Cd36 } & Forward: 5'-GCCAAGCTATTGCGACATGA-3' \\
\hline & Reverse: 5'-AAAAGAATCTCAATGTCCGAGACTTT-3' \\
\hline \multirow{2}{*}{ Cpt1b } & Forward: 5'-GCCCCCTCATGGTGAACAG-3' \\
\hline & Reverse: 5'-TGGCGTGAACGGCATTG-3' \\
\hline \multirow{2}{*}{ Acaca } & Forward: 5'-ATGTCCGCACTGACTGTAACCA-3' \\
\hline & Reverse: 5'-TGCTCCGCACAGATTCTTCA-3' \\
\hline \multirow{2}{*}{ Acox1 } & Forward: 5'-TGTGACCCTTGGCTCTGTTCT-3' \\
\hline & Reverse: 5'-TGTAGTAAGATTCGTGGACCTCTG-3' \\
\hline \multirow{2}{*}{ Acadvl } & Forward: 5'-AGACGGAGGACAGGAATCGG-3' \\
\hline & Reverse: 5'-ACCACGGTGGCAAATTGATC-3' \\
\hline \multirow{2}{*}{ Nrf1 } & Forward: 5'-TTACTCTGCTGTGGCTGATGG-3' \\
\hline & Reverse: 5'-CCTCTGATGCTTGCGTCGTCT-3' \\
\hline \multirow{2}{*}{ Nrf2 } & Forward: 5'-AGACACCAGTGGATCCGCCAG-3' \\
\hline & Reverse: 5'-TGAGGGACTGGGCCTGATGAG-3' \\
\hline \multirow{2}{*}{ Nd1 } & Forward: 5'-CGGCCCATTCGCGTTATTCTT-3' \\
\hline & Reverse: 5'-TGATCGTAACGGAAGCGTGGA-3' \\
\hline \multirow{2}{*}{ Ucp3 } & Forward: 5'-GGATTTGTGCCCTCCTTTCTG-3' \\
\hline & Reverse: 5'-CATTAAGGCCCTCTTCAGTTGCT-3' \\
\hline \multirow{2}{*}{ Il6 } & Forward: 5'-GCTACCAAACTGGATATAATCAGGAAA-3' \\
\hline & Reverse: 5'-CTTGTTATCTTTTAAGTTGTTCTTCATGTACTC-3' \\
\hline \multirow{2}{*}{$\operatorname{Tnf}$} & Forward: 5'-CATCTTCTCAAAATTCGAGTGACAA-3' \\
\hline & Reverse: 5'-TGGGAGTAGACAAGGTACAACCC-3' \\
\hline \multirow{2}{*}{ Ppara } & Forward: 5'-ATGATGGGAGAAGATAAAATCAAGTTC-3' \\
\hline & Reverse: 5'-CGGCTTCTACGGATCGTTTC-3' \\
\hline \multirow{2}{*}{ Ppard } & Forward: 5'-TGTGCAGCGGTGTGGGTAT-3' \\
\hline & Reverse: 5'-GTCATAGCTCTGCCACCATCTG-3' \\
\hline \multirow{2}{*}{ Pparg } & Forward: 5'-GAAGTTCAATGCACTGGAATTAGATG-3' \\
\hline & Reverse: 5'-CCTCGATGGGCTTCACGTT-3' \\
\hline \multirow{2}{*}{ Cyclophilin A } & Forward: 5'-TTCCTCCTTTCACAGAATTATTCCA-3' \\
\hline & Reverse: 5'- CCGCCAGTGCCATTATGG-3' \\
\hline
\end{tabular}

\subsection{ATP measurement}

Cellular ATP levels were determined using Cell-Titer-Glo ${ }^{\circledR}$ assay (Promega) according to manufacturer's instructions.

\subsection{Electrophoretic mobility shift assay (EMSA)}

Nuclear extracts were obtained as previously described [32] from HL-1 cells transduced with adenoviral particles. Protein concentration was measured by the BCA protein assay ${ }^{\mathrm{TM}}$. EMSA was performed using $5 \mu \mathrm{g}$ of nuclear extracts and a double-stranded DNA probe containing the consensus binding site for NF-kB (5'AGTTGAGGGGACTTTCCCAGGC-3'; Promega). DNA probe was labelled with $\left[\gamma-{ }^{32} \mathrm{P}\right]-A T P$ by using T4 polynucleotide kinase (Invitrogen) and purified on a Sephadex G-50 column (GE Healthcare). Competition assays were performed by adding an excess of unlabelled probe. Protein-DNA complexes were resolved by electrophoresis at $4{ }^{\circ} \mathrm{C}$ on $5 \%$ polyacrylamide gels. Gels were dried and subjected to autoradiography using a Storage Phosphor Screen (GE Healthcare). Shifted bands were detected using a Personal Molecular Imager ${ }^{\mathrm{TM}}$ System (Bio-Rad).

\subsection{Co-immunoprecipitation}

Cell nuclear extracts were brought to a final volume of $0.5 \mathrm{~mL}$ with IP buffer containing $20 \mathrm{mM}$ Tris, $137 \mathrm{mM} \mathrm{NaCl}, 2$ mM EDTA, 10\% glycerol 
$1 \%$ Igepal for $6 \mathrm{~h}$ at $4{ }^{\circ} \mathrm{C}$ and incubated with $4 \mu \mathrm{g}$ of anti-p65 or an IgG of the same isotope (antibodies from Santa Cruz). Samples were incubated overnight at $4{ }^{\circ} \mathrm{C}$ with protein A-agarose, and agarose beads were collected by centrifugation. Then, pellets were washed with immunoprecipitation (IP) buffer containing protease inhibitors, resuspended in SDS-PAGE sample buffer and boiled for $5 \mathrm{~min}$ at $100^{\circ} \mathrm{C}$. The resulting supernatant was then subjected to electrophoresis on 10\% SDS-PAGE and immunoblot analysis.

\subsection{Statistical Analyses}

Results are expressed as mean \pm standard deviation (SD). Significant differences were established by Student's $t$-test. The correlation between two variables was evaluated using Spearman's correlation coefficient. All data were analysed by using the GraphPad Instat programme (GraphPad Software V2.03). Differences were considered significant at $\mathrm{p}<0.05$.

\section{Results}

\subsection{Shp mRNA levels are induced in heart from mice fed with HFD}

To explore whether glucose intolerance may be related to changes in cardiac Shp expression, we used hearts from animals in which glucose intolerance was induced by HFD [25]. Interestingly, Shp mRNA levels were up-regulated in hearts from HFD-fed mice compared to animals fed with a chow diet $(\sim 1.4$ fold, $\mathrm{p}<0.05)$ (Fig. $1 \mathrm{~A}$ ), and positively correlated to the AUC values from the glucose tolerance test $(r=0.6848$, $\mathrm{p}<0.05$ ) (Fig. 1B). Therefore, the data suggest that HFD-induced SHP upregulation may either be an innocent secondary effect or directly contribute to the development of cardiac insulin resistance. To further evaluate key downstream factors involved in glucose metabolism, the expression of G6p, Pepck, Glut4 and Pdk4 were analysed, finding a slight but significant reduction ( $18 \%$ reduction, $\mathrm{p}<0.05$ ) in the Glut 4 mRNA levels in the hearts from HFD-fed mice (Fig. 1C).

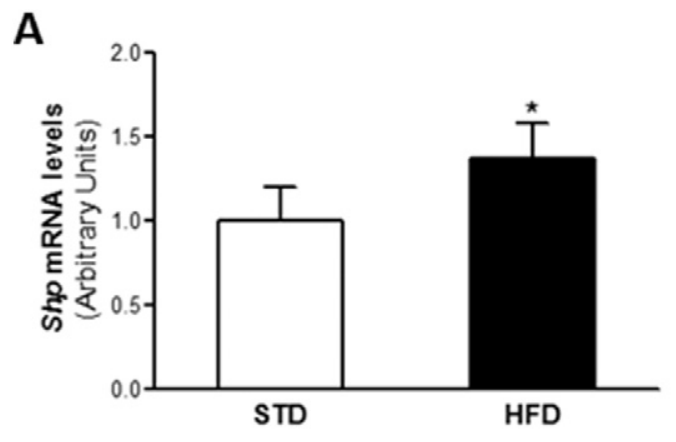

\subsection{SHP overexpression impairs glucose uptake and insulin signalling}

To explore the role of SHP in insulin responsiveness of cardiac myocytes, HL-1 cells were transduced with recombinant adenovirus in order to overexpress SHP. Alternatively, HL-1 cells were challenged with $\mathrm{HP} / \mathrm{HI}$ to render the cells insulin resistant. Insulin stimulation induced glucose uptake in both non-transduced control (CT) and AdGFP (Ad) transduced cells ( 1.4 fold, $\mathrm{p}<0.001$ ) (Fig. 2A and C) showing that insulin responsiveness was not affected due to viral transduction. Interestingly, SHP overexpression caused a reduction in both basal and insulin-stimulated glucose uptake (Fig. 2C) similar to the findings in $\mathrm{HP} / \mathrm{HI}$ challenged cells (Fig. 2A). To explore the role of SHP in the insulin signalling pathway, AKT and AS160 phosphorylation were analysed. Consistent with data from Fig. 2A and C, HP/HI stimulation and SHP overexpression prevented both basal and insulin-stimulated AKT and AS160 (Fig. 2B and D) phosphorylation, suggesting that impairment in the insulin signalling pathway could be related to the changes observed in cellular glucose uptake. Additionally, SHP overexpression also prevented the insulin-stimulated glucose uptake in primary cultures of rat cardiomyocytes (Fig. 2E). To further characterize the role of SHP overexpression in the insulin resistance response in cardiomyocytes, the expression of Socs3, a protein involved in the inhibition of insulin signalling [33], was evaluated. In line with our expectations, SHP overexpression enhanced Socs3 mRNA levels ( 1.7 -fold, $\mathrm{p}<0.05)$ (Fig. 3A). SOCS3 promotes IRS-1 proteasomal degradation [34]. Accordingly, we found a reduction in the IRS-1 protein levels in SHP overexpressing cells (Fig. 3B). Altogether, these results show that both SHP overexpression and $\mathrm{HP} / \mathrm{HI}$ exposure each lead to insulin resistance in cardiac myocytes.

\subsection{SHP overexpression enhances intramyocellular lipid storage}

Because insulin resistance and decreases in insulin-stimulated glucose uptake are closely related to intramyocellular lipid accumulation [18], we explored whether SHP over-expression affects

B

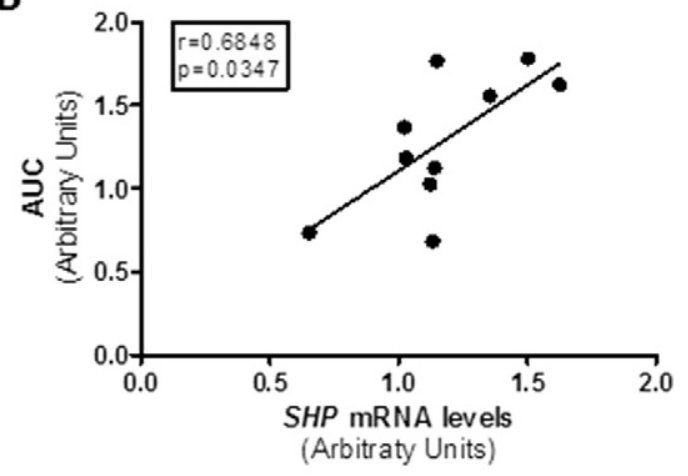

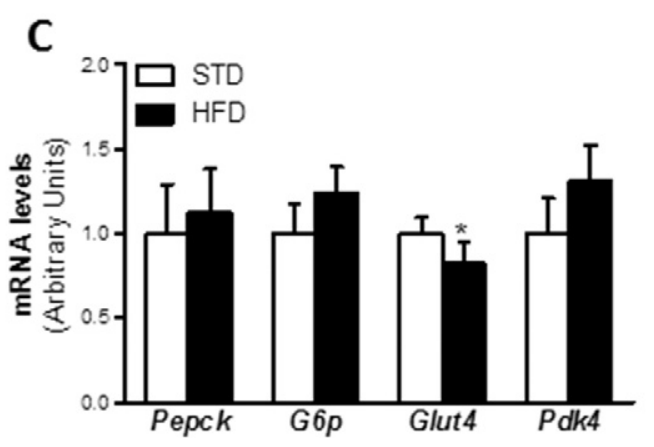

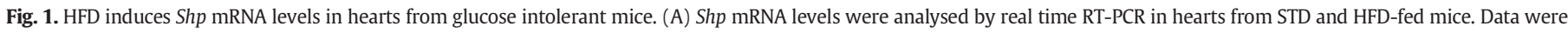

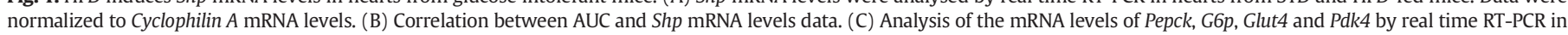
hearts from STD and HFD-fed mice. Data were normalized to Cyclophilin A mRNA levels. Data are expressed as mean \pm SD of 5 mice per group. ( ${ }^{*} p<0.05$ vs. STD-fed mice). 
A

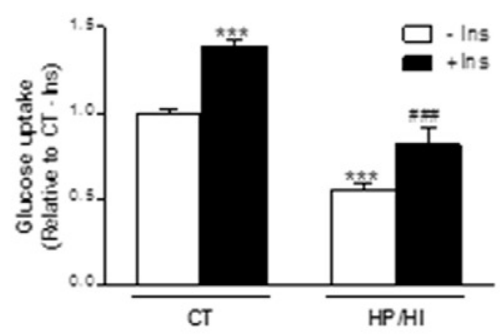

C

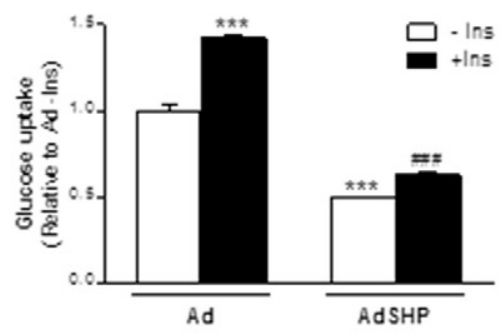

$\mathbf{E}$

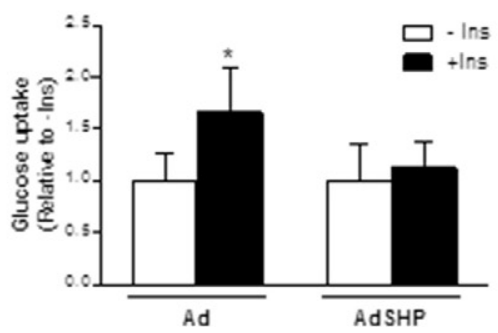

B
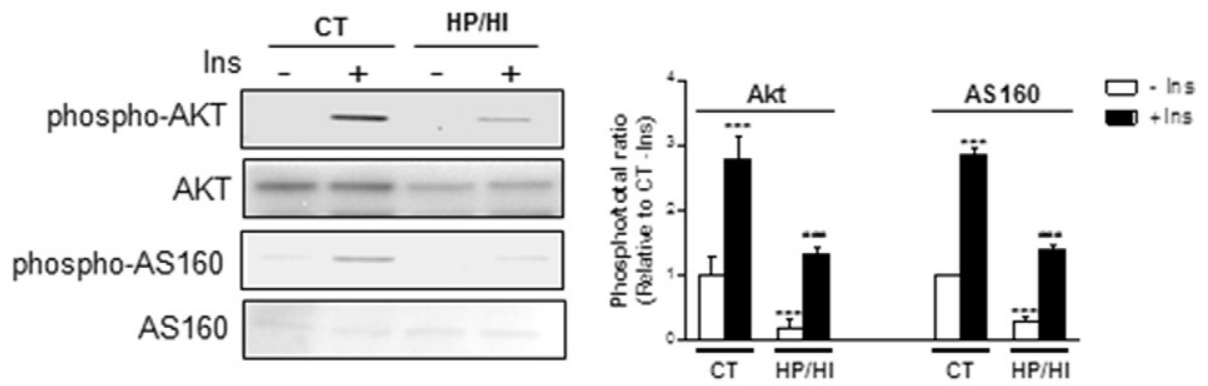

D
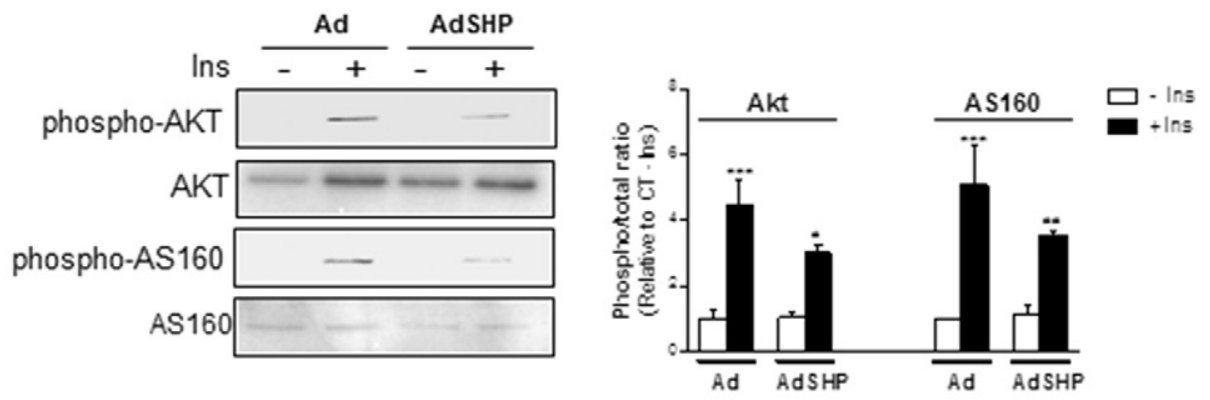

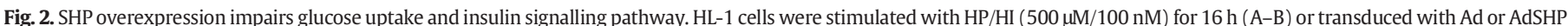

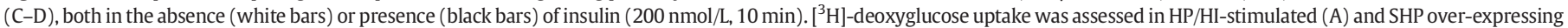

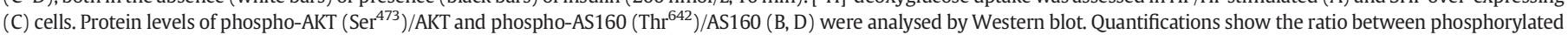

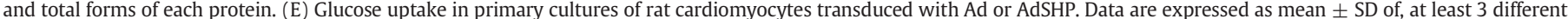

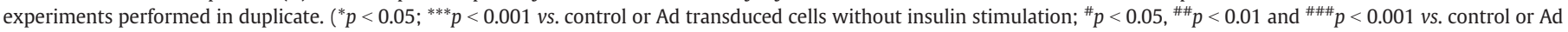
transduced cells stimulated with insulin).

intramyocellular lipid content. Oil-Red-O staining revealed that SHP overexpressing HL- 1 cells exhibited a 3.7 -fold $(p<0.01)$ increase in intramyocellular lipid storage compared to cells transduced with the empty vector (Fig. 4A and B). In agreement with the augmented lipid content, SHP overexpression raised mRNA levels of the membrane fatty acid transporter $C d 36$ ( 6.2 fold; $\mathrm{p}<0.001$ ) (Fig. 4C), without changes in Acot1 expression encoding for acyl-CoA thioesterase 1 (data not shown), which hydrolyses fatty acyl-CoAs to free fatty acids and CoA. Lipid storage is often due to increased fatty acid uptake exceeding mitochondrial $\beta$-oxidation capacity [2]. Furthermore, SHP overexpression affected the expression of specific genes involved in fatty acid metabolism. Thus, no changes were found in the mRNA levels of Cpt1b (Fig. 5A), which catalyses the entry of long-chain fatty acids into the mitochondrial matrix. Interestingly, Acaca was reduced in SHP overexpressing cells $(42 \%, \mathrm{p}<0.05)$ (Fig. $5 \mathrm{~A})$. In addition, the Acaca protein product, ACC, showed enhanced phosphorylation in SHP overexpressing cells (Fig. 5B). Once ACC is phosphorylated, the production of the allosteric CPT1B inhibitor malonyl-CoA is reduced, indicating an increased flux of fatty acids into mitochondria. Once inside mitochondria, fatty acyl-thioesters can undergo $\beta$-oxidation through enzymes including Acox 1 or Acadvl. Therefore, we evaluated the expression of these genes in SHP overexpressing cells. Whereas SHP overexpression did not induce changes in the Acox 1 mRNA levels, it significantly raised Acadvl expression $(\sim 1.8$ fold; $\mathrm{p}<0.05)$ (Fig. 5A).

\subsection{SHP over-expression impairs mitochondrial function}

Once long-chain and very-long-chain fatty acids are oxidized, they provide reducing equivalents (NADH) which are metabolized in the respiratory chain, resulting in the generation of an electrochemical gradient of protons, generally used to produce ATP via oxidative phosphorylation [35]. Nevertheless, under some circumstances, ATP synthesis can be impaired because of the proton electrochemical gradient dissipation through the UCPs, placed in the inner mitochondrial 
A

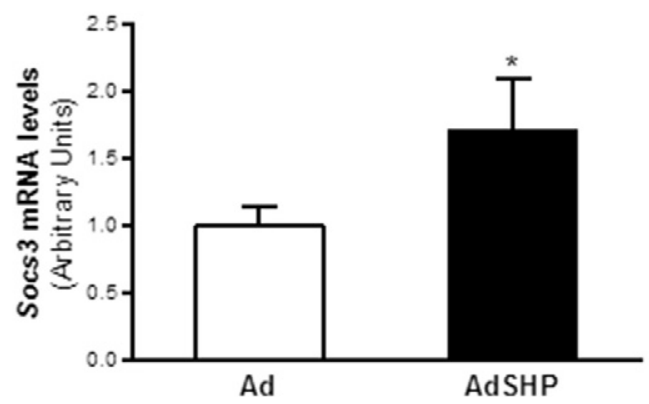

B

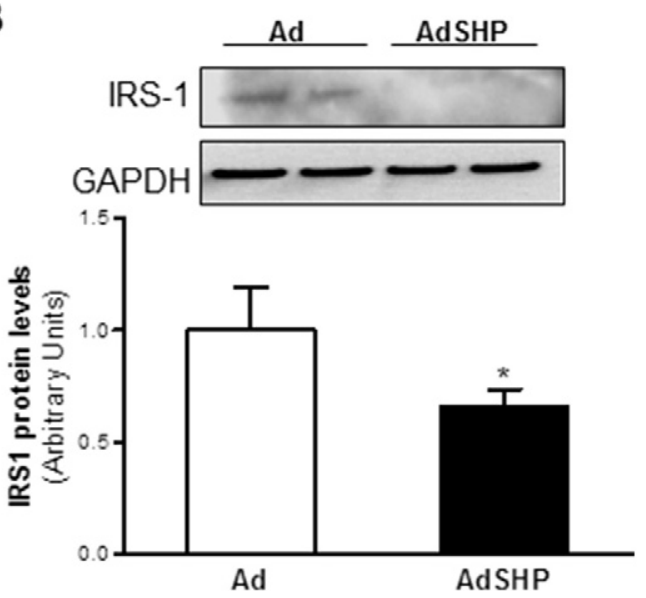

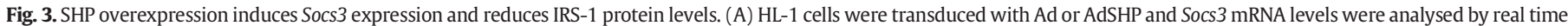

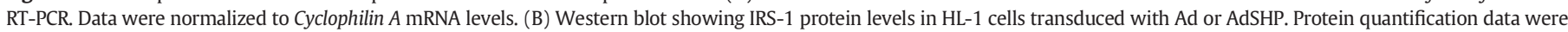
normalized to GAPDH and expressed as mean \pm SD of at least 3 different experiments. ( ${ }^{*} p<0.05 v s$. Ad transduced cells).

membrane [36]. To explore whether SHP overexpression may contribute to mitochondrial dysfunction, we determined the expression of Nrf1 and Nrf2, both involved in the control of DNA mitochondrialencoded genes, such as the subunit 1 of complex I (NADH dehydrogenase subunit 1, ND1), as well as Nd1 and Ucp3. Despite no changes were found in $\mathrm{Nrf1}$ and $\mathrm{Nd1}$ mRNA levels, the expression of $\mathrm{Nrf2}$ was up-regulated in SHP over-expressing cells (Fig. 6A). Accordingly, SHP over-expression induced the protein levels of the succinate dehydrogenase complex iron sulfur subunit B Complex II (CII-SDHB) of the mitochondrial respiratory chain $(\sim 4$ fold, $\mathrm{p}<0.01)$ (Fig. $6 \mathrm{~B})$, as well as the mitochondrial inner membrane potential (Fig. 6C). Ucp3 mRNA levels were induced $(\sim 2.9$ fold, $\mathrm{p}<0.05)$ (Fig. $6 \mathrm{~A})$, whereas ATP levels were reduced ( $34 \%$ reduction, $\mathrm{p}<0.001$ ) in SHP over-expressing cells.

\subsection{SHP overexpression induced NF- $\kappa B$ activation in cardiomyocytes}

Intramyocellular lipid storage may activate Ser/Thr-kinase cascades, activating the pro-inflammatory transcription factor NF- $\kappa B$ [5], and thereby linking the low-grade inflammatory process with metabolic disorders, such as insulin resistance. To explore whether the SHP-induced lipid accumulation was related to a rise in the inflammatory response, the expression of the pro-inflammatory genes Il6 and Tnf was
A
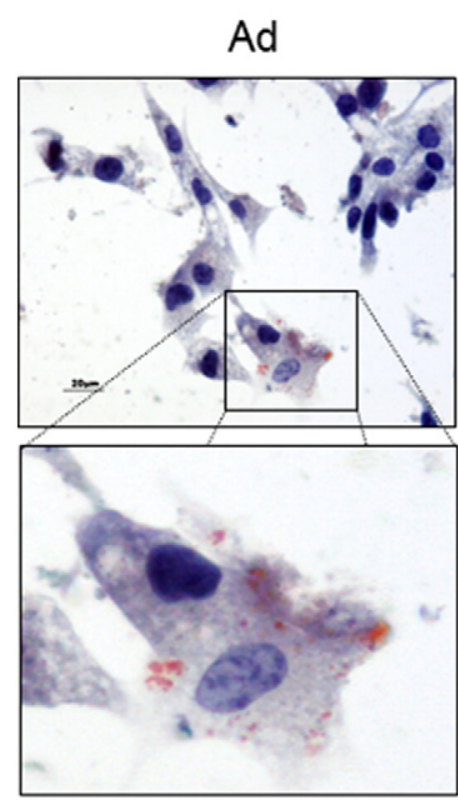
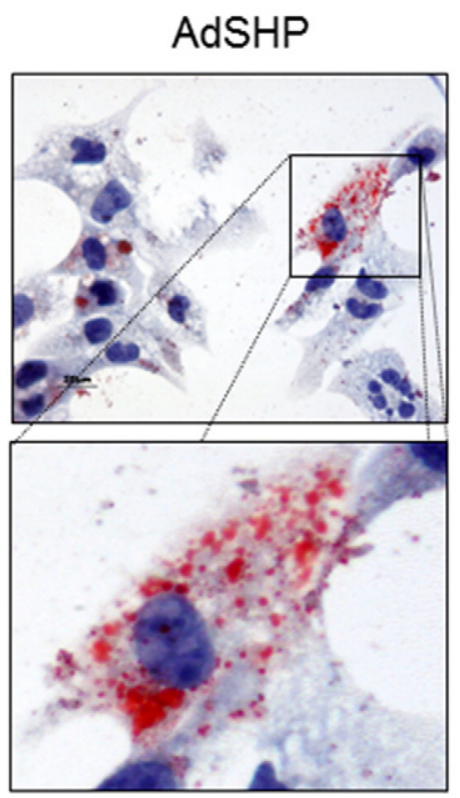

B

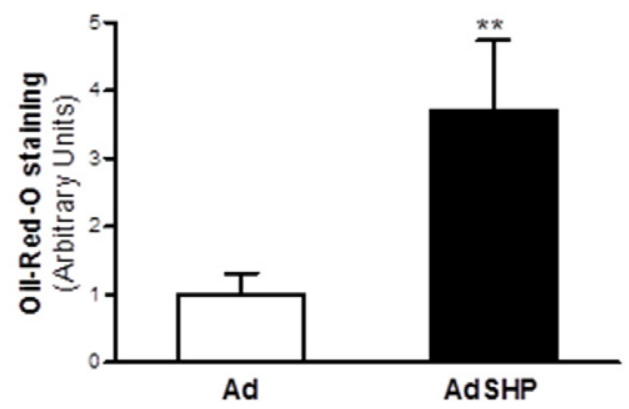

C

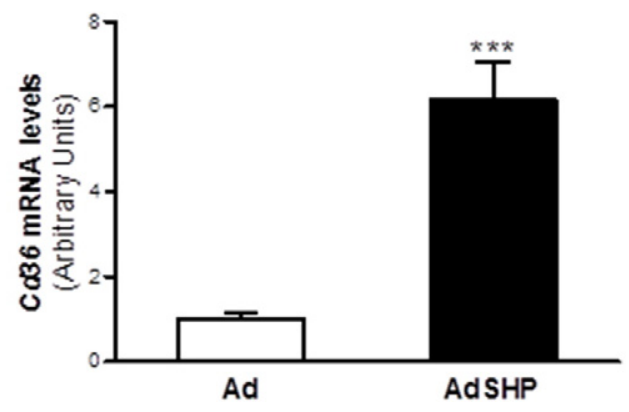

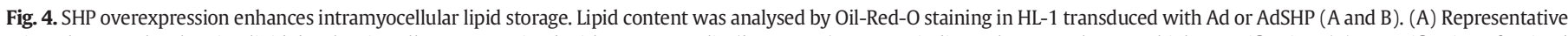

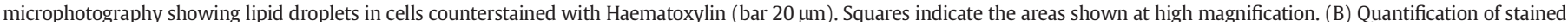

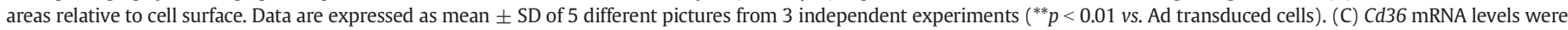

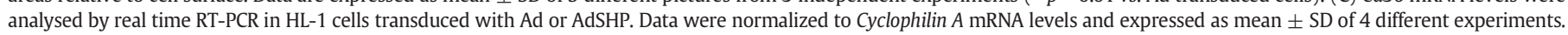
$\left({ }^{* * *} p<0.001\right.$ vs. Ad transduced cells). 
A

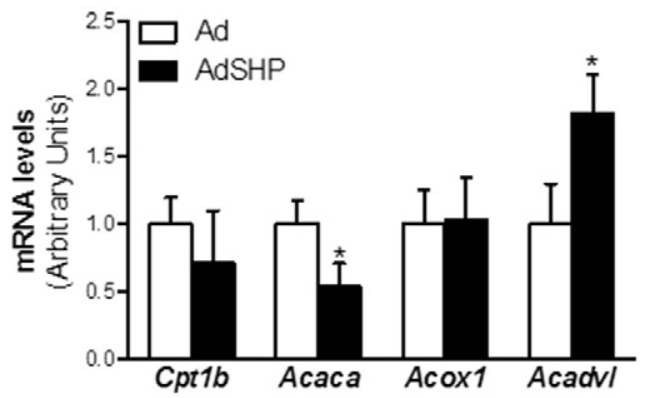

B

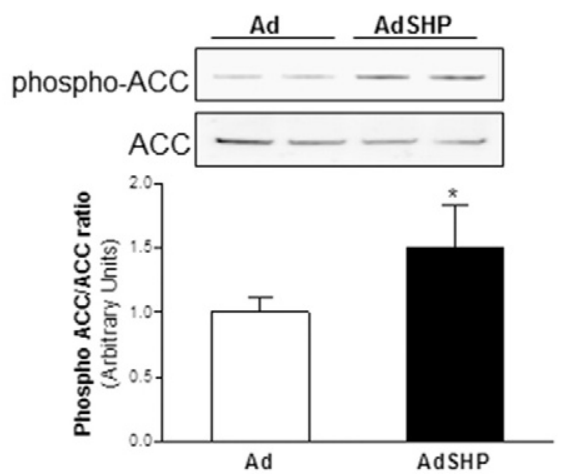

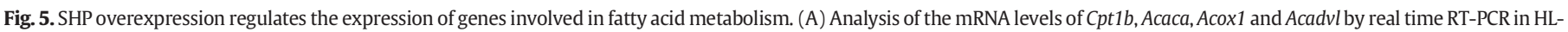

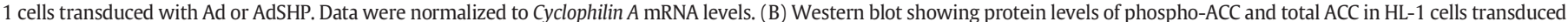

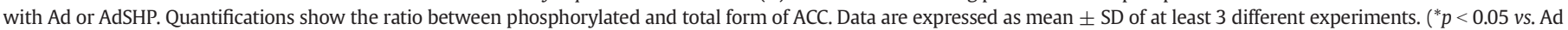
transduced cells).

evaluated. Along with increased lipid storage, SHP overexpression strongly augmented the mRNA levels of both messengers ( 4-fold induction, $\mathrm{p}<0.01$ ) (Fig. 7A and B). Because these genes are under the transcriptional control of NF-kB, we tested the DNA-binding activity of this pro-inflammatory transcription factor in SHP overexpressing cells. EMSA studies showed the formation of a single specific complex, which disappeared in competition assays with an excess of unlabelled probe (Fig. 7C, left). In agreement with the up-regulation of pro-inflammatory genes, SHP overexpression increased NF-KB DNA-binding activity (Fig. 7C, right).

\subsection{Decreased p65-PPAR $\alpha$ interaction in SHP over-expressing cells}

Metabolism and inflammation both are regulated by peroxisome proliferator-activated receptors (PPARs) in cardiomyocytes [26,37-
39]. Interestingly, alterations in the cardiac expression of PPARs are related to cardiac lipotoxicity, contributing to metabolic disturbances related to insulin resistance and diabetic heart [40-45]. Therefore, we explored the PPAR gene expression profile in SHP overexpressing cells. As is shown in Fig. 8A, SHP overexpression did not affect the mRNA levels of Ppard. However, SHP over-expression reduced the Ppara expression (79\% reduction, $\mathrm{p}<0.001$ ) and strongly induced the Pparg mRNA levels ( $\sim 58$-fold induction, $\mathrm{p}<0.001$ ) (Fig. 8A), together reflecting a similar profile to that found in the diabetic heart.

Finally, we further investigated the molecular mechanism by which SHP overexpression increases NF- $\kappa \mathrm{B}$ activation in cardiac cells. PPAR activities are generally reduced by NF- $\kappa \mathrm{B}$ activation $[38,44]$. Vice versa, PPAR $\alpha$ may inhibit NF- $\kappa B$ signalling through different mechanisms, including physical interaction between PPAR $\alpha$ and the p 65 subunit of NF$\kappa \mathrm{B}[46]$. In order to evaluate whether the reduction in PPAR $\alpha$ expression
A

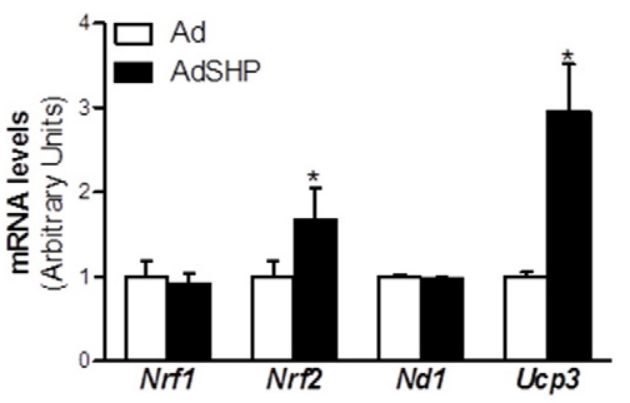

C

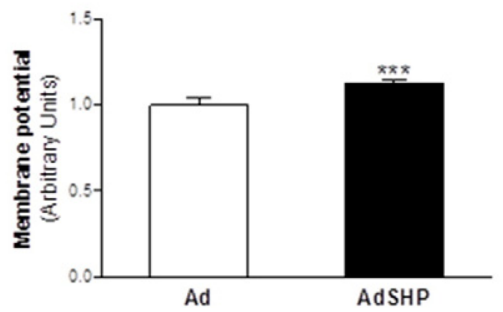

B

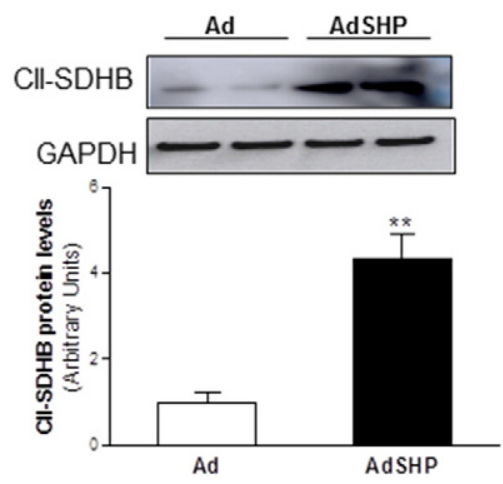

D

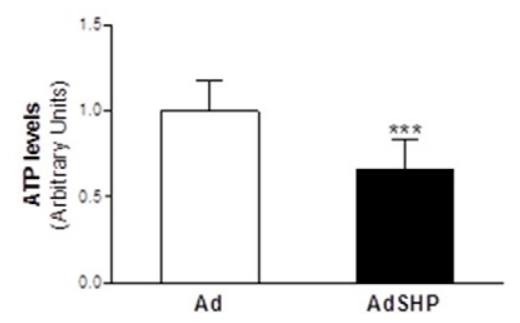

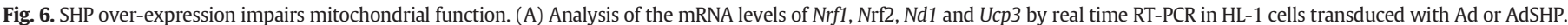

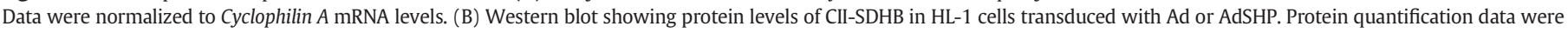

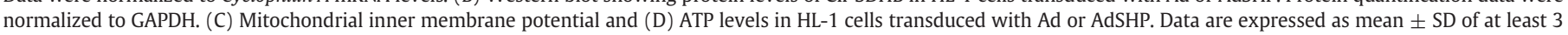
different experiments. $\left({ }^{*} p<0.05 ;{ }^{* *} p<0.01\right.$ and ${ }^{* * *} p<0.001 v s$. Ad transduced cells). 
A

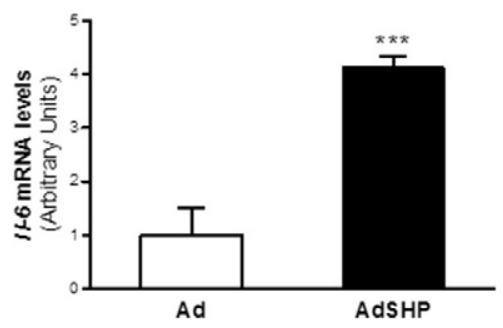

B

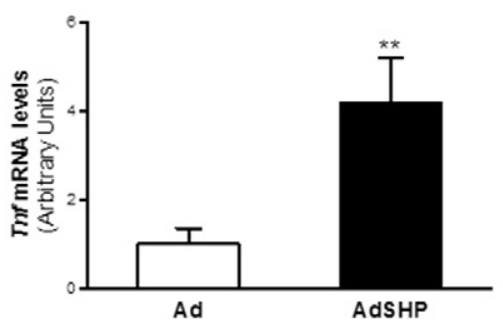

C

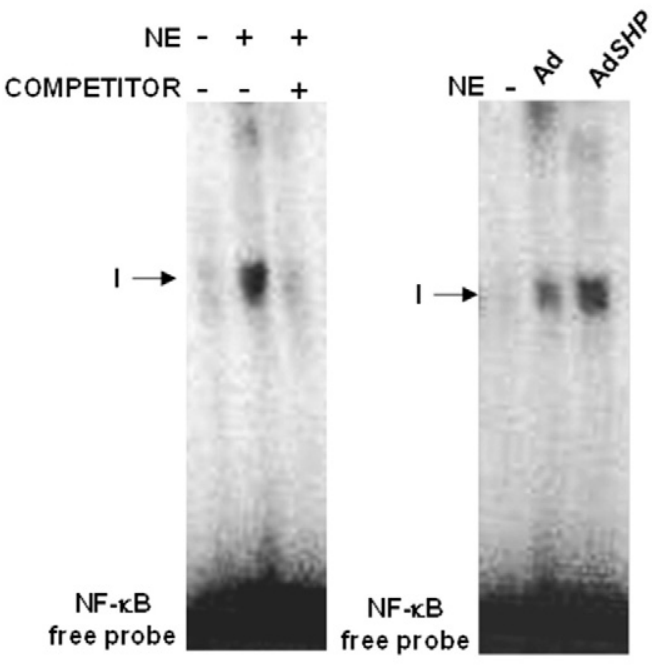

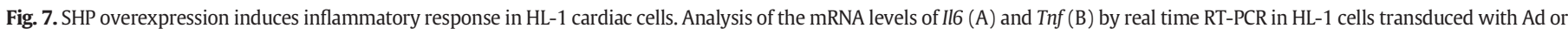

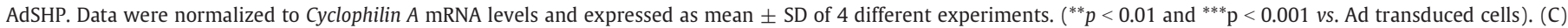

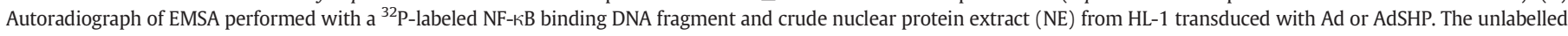
DNA probe is used as competitor. The specific NF-kB/DNA complex is indicated by arrows.

may affect its interaction with NF- $\kappa$ B in SHP overexpressing cells, we performed co-immunoprecipitation assays. Isolated nuclear extracts were immunoprecipitated using antibodies against the p65 subunit of NF- $\kappa \mathrm{B}$, subjected to SDS-PAGE, and immunoblotted with antibodies against PPAR $\alpha$. SHP overexpression strongly reduced the physical interaction between $\mathrm{p} 65$ and PPAR $\alpha$ (Fig. 7B), suggesting that dissociation of

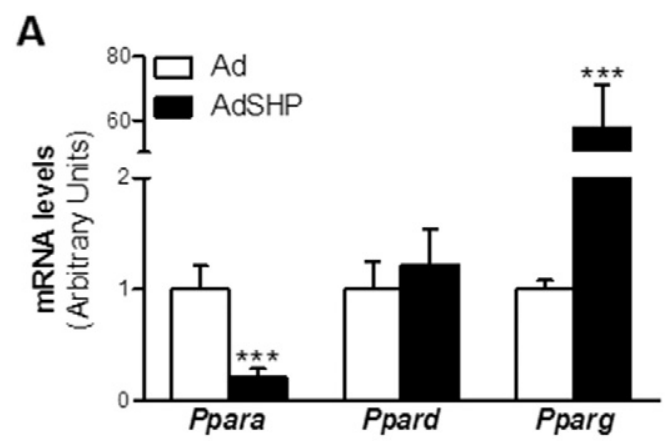

B

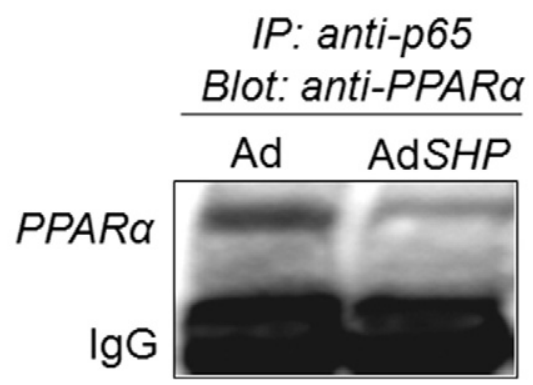

Fig. 8. SHP overexpression modulates the PPAR gene expression profile and promotes dissociation between PPAR $\alpha$ and the p65 subunit of NF- $\kappa$ B. (A) Analysis of mRNA levels of Ppara, Ppard and Pparg by real time RT-PCR in HL-1 cells transduced with Ad or AdSHP. Data were normalized to Cyclophilin A mRNA levels and expressed as mean \pm SD of 4 different experiments. ( ${ }^{* * *} \mathrm{p}<0.001 \mathrm{vs}$. Ad transduced cells). (B) Nuclear extracts from HL-1 transduced with Ad or AdSHP were subjected to immunoprecipitation using anti-p65 antibody coupled to protein A-agarose beads. Immunoprecipitates were subjected to SDS-PAGE and immunoblotted with anti-PPAR $\alpha$ antibodies. Displayed data are representative of three separate experiments. the PPAR $\alpha-N F-\kappa B$ protein complex may enable NF- $\kappa$ B transactivation and the development of the inflammatory response seen in SHP overexpressing cells.

\section{Discussion}

DM2 related alterations are especially relevant in the heart, because the myocardium needs to produce energy constantly, using both glucose and fatty acids, in order to maintain proper cardiac function. Despite advances in DM2 research, the prevalence of this disease is steadily rising worldwide [47]. The lack of an effective therapy for DM2 and its related disturbances such as DCM are alarming. Therefore, it is necessary to identify new emerging molecular targets for the potential treatment of the diabetic heart. In the present study, we found that SHP, an atypical nuclear receptor involved in the regulation of peripheral insulin resistance [9], was induced in hearts from mice fed with a HFD and which displayed glucose intolerance compared with animals fed with a chow diet [25]. Hearts from these animals did not show changes in the expression of genes involved in gluconeogenesis, but yes a slight but significant reduction in Glut4 mRNA levels. Interestingly, cardiac SHP deficiency induces cardiac hypertrophy [17]. Given that during cardiac hypertrophy there is a shift in the substrate preference by heart, from fatty acids to glucose [48-50], these animals could show an increase in glucose utilization. However, the short period of feeding with HFD probably did not cause any structural changes or functional derangements in our animal model. These novel observations suggest that the induction of cardiac Shp expression after the HFD challenge could be related to the onset of the heart metabolic dysregulation mediated by the dietary fat. This hypothesis was further supported by subsequent data showing a positive correlation between the cardiac Shp mRNA levels and glucose intolerance, as measured by the AUC from the glucose tolerance test. Therefore, to explore the mode of action of SHP in cardiac metabolism we overexpressed this nuclear receptor in HL-1 cardiomyocytes.

At the cellular level, we demonstrate for the first time that SHP overexpression mimics the insulin resistance response elicited by a combination of $\mathrm{HP} / \mathrm{HI}$ exposure in cardiomyocytes. It has been previously shown that in liver, SHP inhibits gluconeogenesis [10-15,51] and improves insulin sensitivity [16] promoting the glucose delivery to mitochondria [13]. However, our data revealed that in HL-1 
cardiomyocytes, SHP overexpression reduced both basal and insulinstimulated glucose uptake, in similar degrees to those found in $\mathrm{HP} / \mathrm{HI}$ challenged cells. In agreement with this, the insulin signalling pathway, analysed by AKT and AS160 phosphorylation, was also impaired in both models of cardiac insulin resistance. Insulin resistance was further analysed determining the expression of Socs3 [33]. Despite it has been previously shown that in hepatocytes SHP improves insulin sensitivity via inhibition of the STAT-3/SOCS-3 pathway [16], Socs3 mRNA levels were induced in SHP over-expressing cells. This data was in line with increased Socs 1 and Socs 3 expression found in heart from HFD-fed mice [26]. Furthermore, SHP overexpression reduced the IRS-1 protein levels, suggesting that SHP may promote the SOCS-3-induced IRS-1 proteasomal degradation. Taken together, our data indicate that SHP may drive opposite responses in hepatocytes and cardiomyocytes. The discrepant role of SHP between these two tissues may be consequence of their different metabolic functions. While liver in the systemic context may be considered as an anabolic tissue, mainly involved in biosynthesis processes such as gluconeogenesis or triglyceride synthesis, heart is a catabolic organ that needs to produce energy constantly for maintaining its function. Thus, SHP could act as mediator differentially controlling physiological responses in various tissues.

Insulin resistance is commonly linked to intramyocellular lipid accumulation [52]. The increase in lipid mediators has been associated with cardiac dysfunction [53,54], and vice versa cardiac function improved with their reduction [53]. According to the observed role of SHP as an originator of insulin resistance, we found increased lipid droplets in SHP over-expressing cells compared with those of controls. Consistent with this, the expression of the membrane fatty acid transporter $\mathrm{Cd} 36$ was augmented in SHP overexpressing cells, with no changes in Acot1 expression. These data suggested a positive flux of activated fatty acids into cardiomyocytes, as demonstrated with an increase in OilRed-O staining. Accumulated fatty acids can be used for lipid storage or channelled into mitochondria for oxidation. Reduction in the mRNA levels of Acaca and the up-regulation of Acadvl and Ucp3 in SHP over-expressing cells indicated a reprogramming in the expression of genes involved in fatty acid $\beta$-oxidation. Notably, increased Ucp3 activity in skeletal muscle has been associated with increased fatty acid oxidation rates [55]. However, because the heart needs to produce energy constantly, induction of Ucp3 expression has been previously reported in diabetic hearts as a hallmark of contractile dysfunction [56]. The induction of Ucp3 mRNA level was in parallel with decreased ATP levels in SHP over-expressing cells, which may reflect that increased fatty acid oxidation and mitochondrial respiration are less efficient for energy production upon Ucp3 induction [57].

Intramyocellular lipid accumulation is associated with the activation of the pro-inflammatory transcription factor NF- $\kappa$ B and abnormal cytokine production, thereby linking metabolic disorders with a low-grade inflammatory process [5]. Interestingly, recent work indicated a role of SHP in the inflammatory response, although results were somewhat conflicting. Indeed, while SHP was firstly described as transcriptional co-activator of NF-kB in several cell types [21-24], data from others support an anti-inflammatory role for this nuclear receptor [18-20]. Specifically, the molecular mechanisms by which SHP drives its antiinflammatory effects involved dual regulatory functions in a canonical transcription factor NF-kB signalling pathway, acting as both a repressor of transactivation of the NF- $\mathrm{B}$ subunit p65 and an inhibitor of polyubiquitination of the adaptor TRAF6 [20]. Thus, SHP may be considered as a modifier, able to differentially regulate the transcriptional activity of the same transcription factor, such as NF- $k B$, in function of the cell requirements. To clarify the role of SHP in cardiac inflammation we explored the degree of NF- $k B$ activation. In accordance with a proinflammatory action, SHP over-expression induced the NF- $\kappa$ B DNAbinding activity, as well as the mRNA levels of Il6 and Tnf, two wellknown NF- $\mathrm{B}$ target genes involved in the heart failure progression [58]. Interestingly, a similar pro-inflammatory profile, characterized by increased Il6 and Tnf expression and an enhanced NF-KB DNA-binding activity, was found in the hearts from HFD-fed mice [26], where we observed increased Shp expression. As a result, our data indicates a contribution of SHP to NF- $\kappa$ B activation, and support a pro-inflammatory role of SHP, at least in cardiomyocytes.

PPARs have been proposed as potential modulators of both fatty acid metabolism [37,38,44] and inflammation [26,37-39] in cardiomyocytes. Indeed, changes in the expression/activity of these transcription factors have been previously described in hearts with metabolic disturbances. Our data revealed that SHP overexpression strongly reduced Ppara mRNA levels. This data agrees with the Ppara reduction found in cardiomyocytes chronically exposed to fatty acid excess [43] and in hearts from senescence-accelerated mice with enhanced ceramide levels [44]. Both Ppara and Ppard are expressed in comparable levels in heart and share similar functions in cardiomyocytes regarding fatty acid metabolism [59]. Despite the observed reduction of Ppara expression, no changes were observed in the expression of Ppara targetgenes, such as $C p t 1 b$. However, it was previously reported that PPAR $\delta$ can compensate for the lack of PPAR $\alpha$ [60], which is consistent with our data showing unaltered Ppard expression in SHP overexpressing cells. Unlike other PPARs, Pparg is barely detectable in heart, but it is up-regulated in hearts from rat models of DM2 [41,42,45], thereby contributing to the storage of intramyocellular lipid content [45]. In agreement with this, SHP overexpression strongly induced Pparg, which is in line with the induction of its target gene $C d 36$, setting a potential bridge between changes in Pparg expression and the increased in lipid droplets observed in SHP overexpressing cells. Reduced Pparg and Cd36 expression recently have been found in liver from Shp-deficient mice [61], thus suggesting a direct link between SHP and the regulation of the Pparg expression. The molecular mechanisms underlying such regulation may involve SHP-mediated FXR activation [62] and HNF4 $\alpha$ activation by RAR/Hes6 inhibition [63]. In addition, SHP may act as endogenous enhancer of PPAR $\gamma$ transactivation through a mechanism involving a competition with the nuclear receptor corepressor (NCoR) for the direct binding to PPAR $\gamma$ [64]. However, while SHP acts as endogenous enhancer of PPAR $\gamma$ transactivation [64], it can activate or repress the PPAR $\alpha$ transcriptional activity [65], suggesting the involvement of additional factors in the SHP-mediated transcriptional regulation of PPARs.

It has been previously reported that PPAR $\alpha$ may act through DNAbinding independent mechanisms that involves a physical interaction

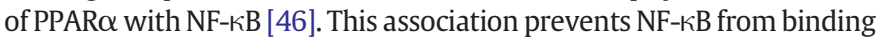
to its response element, thereby inhibiting its ability to induce gene transcription [46]. Here, we demonstrate that SHP overexpression reduced protein-protein association between PPAR $\alpha$ and p65, suggesting that dissociation between these two proteins is one of the mechanisms by which SHP overexpression drives NF- $\kappa$ B activation and the inflammatory response in cardiomyocytes.

In summary, in the present study we show for the first time that ectopic expression of SHP in HL-1 cardiomyocytes induces the accumulation of intramyocellular lipid droplets and changes the expression of genes related to lipid metabolism and mitochondrial uncoupling. The SHP-induced lipid storage correlates to an inflammatory response involving the dissociation of PPAR $\alpha$ from NF- $\kappa B$ and impairment of the insulin signalling pathway. Although further studies are necessary to explore the role of cardiac SHP in the context of normal physiological stimuli, our data show the relevance of this nuclear receptor in processes that have been linked to cardiac dysfunction, suggesting this nuclear receptor as a new potential therapeutic target for DCM.

\section{Funding}

This study was partially supported by funds from The Netherlands Organization for Scientific Research (NWO) (VIDI grant number 864.10.007 to DN), the Spanish Ministerio de Economía y Competitividad (SAF2015-64146-R to MVC) and Fundació la Marató 
TV3 2014 ( to MVC). DC was supported by a Marie Curie fellowship (PIIFGA-2012-332230).

\section{Transparency document}

The Transparency document associated with this article can be found, in online version.

\section{Acknowledgements}

We are indebted to Dr. Hueng-Sik Choi (Hormone Research Center, School of Biological Sciences and Technology, Chonnam National University, Gwangju) for kindly providing us with the Adenoviruses encoding Enhanced Green Fluorescence Protein (Ad) and the full-length human SHP (Ad-SHP).

\section{References}

[1] E. Dirkx, R.W. Schwenk, J.F. Glatz, J.J. Luiken, G.J. van Eys, High fat diet induced diabetic cardiomyopathy, Prostaglandins Leukot. Essent. Fat. Acids 85 (2011) 219-225.

[2] A. Bonen, G.P. Holloway, N.N. Tandon, X.X. Han, J. McFarlan, J.F. Glatz, J.J. Luiken, Cardiac and skeletal muscle fatty acid transport and transporters and triacylglycerol and fatty acid oxidation in lean and Zucker diabetic fatty rats, Am. J. Physiol. Regul. Integr. Comp. Physiol. 297 (2009) R1202-R1212.

[3] D.M. Erion, G.I. Shulman, Diacylglycerol-mediated insulin resistance, Nat. Med. 16 (2010) 400-402

[4] M. Gottlicher, E. Widmark, Q. Li, J.A. Gustafsson, Fatty acids activate a chimera of the clofibric acid-activated receptor and the glucocorticoid receptor, Proc. Natl. Acad. Sci. U. S. A. 89 (1992) 4653-4657.

[5] K.E. Wellen, G.S. Hotamisligil, Inflammation, stress, and diabetes, J. Clin. Invest. 115 (2005) 1111-1119.

[6] A. Ilercil, R.B. Devereux, M.J. Roman, M. Paranicas, J. O'Grady, M.T.K. Welty, D.C. Robbins, R.R. Fabsitz, B.V. Howard, E.T. Lee, Relationship of impaired glucose tolerance to left ventricular structure and function: the Strong Heart Study, Am. Heart J. 141 (2001) 992-998.

[7] W. Seol, H.S. Choi, D.D. Moore, An orphan nuclear hormone receptor that lacks a DNA binding domain and heterodimerizes with other receptors, Science 272 (1996) 1336-1339.

[8] Y. Zhang, C.H. Hagedorn, L. Wang, Role of nuclear receptor SHP in metabolism and cancer, Biochim. Biophys. Acta 1812 (2011) 893-908.

[9] M.K. Kim, D. Chanda, I.K. Lee, H.S. Choi, K.G. Park, Targeting orphan nuclear receptor SHP in the treatment of metabolic diseases, Expert Opin. Ther. Targets 14 (2010) 453-466.

[10] Y.D. Kim, K.G. Park, Y.S. Lee, Y.Y. Park, D.K. Kim, B. Nedumaran, W.G. Jang, W.J. Cho, J. Ha, I.K. Lee, C.H. Lee, H.S. Choi, Metformin inhibits hepatic gluconeogenesis through AMP-activated protein kinase-dependent regulation of the orphan nuclear receptor SHP, Diabetes 57 (2008) 306-314.

[11] J.M. Lee, W.Y. Seo, K.H. Song, D. Chanda, Y.D. Kim, D.K. Kim, M.W. Lee, D. Ryu, Y.H. Kim, J.R. Noh, C.H. Lee, J.Y. Chiang, S.H. Koo, H.S. Choi, AMPK-dependent repression of hepatic gluconeogenesis via disruption of CREB.CRTC2 complex by orphan nuclear receptor small heterodimer partner, J. Biol. Chem. 285 (2010) 32182-32191.

[12] Y.D. Kim, T. Li, S.W. Ahn, D.K. Kim, J.M. Lee, S.L. Hwang, Y.H. Kim, C.H. Lee, I.K. Lee, J.Y. Chiang, H.S. Choi, Orphan nuclear receptor small heterodimer partner negatively regulates growth hormone-mediated induction of hepatic gluconeogenesis through inhibition of signal transducer and activator of transcription 5 (STAT5) transactivation, J. Biol. Chem. 287 (2012) 37098-37108.

[13] Y.D. Kim, Y.H. Kim, S. Tadi, J.H. Yu, Y.H. Yim, N.H. Jeoung, M. Shong, L. Hennighausen, R.A. Harris, I.K. Lee, C.H. Lee, H.S. Choi, Metformin inhibits growth hormone-mediated hepatic PDK4 gene expression through induction of orphan nuclear receptor small heterodimer partner, Diabetes 61 (2012) 2484-2494.

[14] D. Chanda, Y.B. Xie, H.S. Choi, Transcriptional corepressor SHP recruits SIRT1 histone deacetylase to inhibit LRH-1 transactivation, Nucleic Acids Res. 38 (2010) 4607-4619.

[15] J.Y. Kim, H.J. Kim, K.T. Kim, Y.Y. Park, H.A. Seong, K.C. Park, I.K. Lee, H. Ha, M. Shong, S.C. Park, H.S. Choi, Orphan nuclear receptor small heterodimer partner represses hepatocyte nuclear factor 3/Foxa transactivation via inhibition of its DNA binding, Mol. Endocrinol. 18 (2004) 2880-2894.

[16] Y.D. Kim, Y.H. Kim, Y.M. Cho, D.K. Kim, S.W. Ahn, J.M. Lee, D. Chanda, M. Shong, C.H. Lee, H.S. Choi, Metformin ameliorates IL-6-induced hepatic insulin resistance via induction of orphan nuclear receptor small heterodimer partner (SHP) in mouse models, Diabetologia 55 (2012) 1482-1494.

[17] Y.S. Nam, Y. Kim, H. Joung, D.H. Kwon, N. Choe, H.K. Min, Y.S. Kim, H.S. Kim, D.K. Kim, Y.K. Cho, Y.H. Kim, K.I. Nam, H.C. Choi, D.H. Park, K. Suk, I.K. Lee, Y. Ahn, C.H. Lee, H.S. Choi, G.H. Eom, H. Kook, Small heterodimer partner blocks cardiac hypertrophy by interfering with GATA6 signaling, Circ. Res. 115 (2014) 493-503.

[18] Y.T. Li, K.E. Swales, G.J. Thomas, T.D. Warner, D. Bishop-Bailey, Farnesoid x receptor ligands inhibit vascular smooth muscle cell inflammation and migration, Arterioscler. Thromb. Vasc. Biol. 27 (2007) 2606-2611.

[19] C.S. Yang, J.M. Yuk, J.J. Kim, J.H. Hwang, C.H. Lee, J.M. Kim, G.T. Oh, H.S. Choi, E.K. Jo, Small heterodimer partner-targeting therapy inhibits systemic inflammatory responses through mitochondrial uncoupling protein 2, PLoS ONE 8 (2013), e63435.
[20] J.M. Yuk, D.M. Shin, H.M. Lee, J.J. Kim, S.W. Kim, H.S. Jin, C.S. Yang, K.A. Park, D. Chanda, D.K. Kim, S.M. Huang, S.K. Lee, C.H. Lee, J.M. Kim, C.H. Song, S.Y. Lee, G.M Hur, D.D. Moore, H.S. Choi, E.K. Jo, The orphan nuclear receptor SHP acts as a negative regulator in inflammatory signaling triggered by Toll-like receptors, Nat. Immunol. 12 (2011) 742-751.

[21] F. Murshed, L. Farhana, M.I. Dawson, J.A. Fontana, NF-kappaB p65 recruited SHP regulates PDCD5-mediated apoptosis in cancer cells, Apoptosis 19 (2014) 506-517.

[22] K. Kim, Y.H. Choi, H.H. Kim, J. Cheong, The orphan nuclear receptor SHP inhibits apoptosis during the monocytic differentiation by inducing p21WAF1, Exp. Mol. Med. 41 (2009) 429-439.

[23] Y.S. Kim, C.Y. Han, S.W. Kim, J.H. Kim, S.K. Lee, D.J. Jung, S.Y. Park, H. Kang, H.S. Choi, J.W. Lee, Y.K. Pak, The orphan nuclear receptor small heterodimer partner as a novel coregulator of nuclear factor-kappa b in oxidized low density lipoprotein-treated macrophage cell line RAW 264.7, J. Biol. Chem. 276 (2001) 33736-33740.

[24] L. Farhana, M.I. Dawson, J.H. Dannenberg, L. Xu, J.A. Fontana, SHP and Sin3A expression are essential for adamantyl-substituted retinoid-related molecule-mediated nuclear factor-kappaB activation, c-Fos/c-Jun expression, and cellular apoptosis, Mol. Cancer Ther. 8 (2009) 1625-1635.

[25] E. Barroso, R. Rodriguez-Calvo, L. Serrano-Marco, A.M. Astudillo, J. Balsinde, X Palomer, M. Vazquez-Carrera, The PPARbeta/delta activator GW501516 prevents the down-regulation of AMPK caused by a high-fat diet in liver and amplifies the PGC-1alpha-Lipin 1-PPARalpha pathway leading to increased fatty acid oxidation, Endocrinology 152 (2011) 1848-1859.

[26] D. Alvarez-Guardia, X. Palomer, T. Coll, L. Serrano, R. Rodriguez-Calvo, M.M. Davidson, M. Merlos, I. El Kochairi, L. Michalik, W. Wahli, M. Vazquez-Carrera, PPARbeta/delta activation blocks lipid-induced inflammatory pathways in mouse heart and human cardiac cells, Biochim. Biophys. Acta 1811 (2011) 59-67.

[27] L. Salvado, E. Barroso, A.M. Gomez-Foix, X. Palomer, L. Michalik, W. Wahli, M Vazquez-Carrera, PPARbeta/delta prevents endoplasmic reticulum stress-associated inflammation and insulin resistance in skeletal muscle cells through an AMPK-dependent mechanism, Diabetologia 57 (2014) 2126-2135.

[28] J.J. Luiken, F.A. van Nieuwenhoven, G. America, G.J. van der Vusse, J.F. Glatz, Uptake and metabolism of palmitate by isolated cardiac myocytes from adult rats: involvement of sarcolemmal proteins, J. Lipid Res. 38 (1997) 745-758.

[29] A. Volz, H.M. Piper, B. Siegmund, P. Schwartz, Longevity of adult ventricular rat heart muscle cells in serum-free primary culture, J. Mol. Cell. Cardiol. 23 (1991) 161-173.

[30] R.W. Schwenk, E. Dirkx, W.A. Coumans, A. Bonen, A. Klip, J.F. Glatz, J.J. Luiken, Requirement for distinct vesicle-associated membrane proteins in insulin- and AMPactivated protein kinase (AMPK)-induced translocation of GLUT4 and CD36 in cultured cardiomyocytes, Diabetologia 53 (2010) 2209-2219.

[31] R. Rodriguez-Calvo, M. Vazquez-Carrera, L. Masana, D. Neumann, AICAR protects against high palmitate/high insulin-induced intramyocellular lipid accumulation and insulin resistance in HL-1 cardiac cells by inducing PPAR-target gene expression, PPAR Res. 2015 (2015) 785783.

[32] R. Rodriguez-Calvo, A. Guadall, O. Calvayrac, M.A. Navarro, J. Alonso, B. Ferran, A. de Diego, P. Muniesa, J. Osada, C. Rodriguez, J. Martinez-Gonzalez, Over-expression of neuron-derived orphan receptor-1 (NOR-1) exacerbates neointimal hyperplasia after vascular injury, Hum. Mol. Genet. 22 (2013) 1949-1959.

[33] H. Shi, B. Cave, K. Inouye, C. Bjorbaek, J.S. Flier, Overexpression of suppressor of cytokine signaling 3 in adipose tissue causes local but not systemic insulin resistance, Diabetes 55 (2006) 699-707.

[34] L. Rui, M. Yuan, D. Frantz, S. Shoelson, M.F. White, SOCS-1 and SOCS-3 block insulin signaling by ubiquitin-mediated degradation of IRS1 and IRS2, J. Biol. Chem. 277 (2002) 42394-42398.

[35] G.C. Brown, Control of respiration and ATP synthesis in mammalian mitochondria and cells, Biochem. J. 284 (Pt 1) (1992) 1-13.

[36] D. Ricquier, F. Bouillaud, The uncoupling protein homologues: UCP1, UCP2, UCP3, StUCP and AtUCP, Biochem. J. 345 (Pt 2) (2000) 161-179.

[37] S. Kersten, B. Desvergne, W. Wahli, Roles of PPARs in health and disease, Nature 405 (2000) 421-424.

[38] A. Planavila, J.C. Laguna, M. Vazquez-Carrera, Atorvastatin improves peroxisome proliferator-activated receptor signaling in cardiac hypertrophy by preventing nuclear factor-kappa B activation, Biochim. Biophys. Acta 1687 (2005) 76-83.

[39] A. Planavila, R. Rodriguez-Calvo, M. Jove, L. Michalik, W. Wahli, J.C. Laguna, M. VazquezCarrera, Peroxisome proliferator-activated receptor beta/delta activation inhibits hypertrophy in neonatal rat cardiomyocytes, Cardiovasc. Res. 65 (2005) 832-841.

[40] T. Haffar, F.A. Berube-Simard, N. Bousette, Cardiomyocyte lipotoxicity is mediated by Il-6 and causes down-regulation of PPARs, Biochem. Biophys. Res. Commun. 459 (2015) 54-59.

[41] T.I. Lee, Y.H. Kao, Y.C. Chen, N.H. Pan, Y.J. Chen, Oxidative stress and inflammation modulate peroxisome proliferator-activated receptors with regional discrepancy in diabetic heart, Eur. J. Clin. Investig. 40 (2010) 692-699.

[42] T.I. Lee, Y.H. Kao, Y.C. Chen, N.H. Pan, Y.K. Lin, Y.J. Chen, Cardiac peroxisomeproliferator-activated receptor expression in hypertension co-existing with diabetes, Clin. Sci. 121 (2011) 305-312.

[43] M.E. Young, S. Patil, J. Ying, C. Depre, H.S. Ahuja, G.L. Shipley, S.M. Stepkowski, P.J Davies, H. Taegtmeyer, Uncoupling protein 3 transcription is regulated by peroxisome proliferator-activated receptor (alpha) in the adult rodent heart, FASEB J. 15 (2001) 833-845.

[44] R. Rodriguez-Calvo, L. Serrano, E. Barroso, T. Coll, X. Palomer, A. Camins, R.M. Sanchez, M. Alegret, M. Merlos, M. Pallas, J.C. Laguna, M. Vazquez-Carrera, Peroxisome proliferator-activated receptor alpha down-regulation is associated with enhanced ceramide levels in age-associated cardiac hypertrophy, J. Gerontol. A Biol. Sci. Med. Sci. 62 (2007) 1326-1336.

[45] B.M. Spiegelman, PPAR-gamma: adipogenic regulator and thiazolidinedione receptor, Diabetes 47 (1998) 507-514. 
[46] P. Delerive, K. De Bosscher, S. Besnard, W. Vanden Berghe, J.M. Peters, F.J. Gonzalez, J.C. Fruchart, A. Tedgui, G. Haegeman, B. Staels, Peroxisome proliferator-activated receptor alpha negatively regulates the vascular inflammatory gene response by negative cross-talk with transcription factors NF-kappaB and AP-1, J. Biol. Chem. 274 (1999) 32048-32054.

[47] V.L. Roger, A.S. Go, D.M. Lloyd-Jones, E.J. Benjamin, J.D. Berry, W.B. Borden, D.M. Bravata, S. Dai, E.S. Ford, C.S. Fox, H.J. Fullerton, C. Gillespie, S.M. Hailpern, J.A Heit, V.J. Howard, B.M. Kissela, S.J. Kittner, D.T. Lackland, J.H. Lichtman, L.D. Lisabeth, D.M. Makuc, G.M. Marcus, A. Marelli, D.B. Matchar, C.S. Moy, D. Mozaffarian, M.E. Mussolino, G. Nichol, N.P. Paynter, E.Z. Soliman, P.D. Sorlie, N Sotoodehnia, T.N. Turan, S.S. Virani, N.D. Wong, D. Woo, M.B. Turner, C. American Heart Association Statistics, S. Stroke Statistics, Heart disease and stroke statistics-2012 update: a report from the American Heart Association, Circulation 125 (2012) e2-e220.

[48] M.F. Allard, P.G. Emanuel, J.A. Russell, S.P. Bishop, S.B. Digerness, P.G. Anderson, Preischemic glycogen reduction or glycolytic inhibition improves postischemic recovery of hypertrophied rat hearts, Am. J. Physiol. 267 (1994) H66-H74.

[49] Y. Kagaya, Y. Kanno, D. Takeyama, N. Ishide, Y. Maruyama, T. Takahashi, T. Ido, T. Takishima, Effects of long-term pressure overload on regional myocardial glucose and free fatty acid uptake in rats. A quantitative autoradiographic study, Circulation 81 (1990) 1353-1361.

[50] T. Doenst, G.W. Goodwin, A.M. Cedars, M. Wang, S. Stepkowski, H. Taegtmeyer, Load-induced changes in vivo alter substrate fluxes and insulin responsiveness of rat heart in vitro, Metab. Clin. Exp. 50 (2001) 1083-1090.

[51] Y.S. Lee, D.K. Kim, Y.D. Kim, K.C. Park, M. Shong, H.A. Seong, H.J. Ha, H.S. Choi, Orphan nuclear receptor SHP interacts with and represses hepatocyte nuclear factor-6 (HNF-6) transactivation, Biochem. J. 413 (2008) 559-569.

[52] N.M. Borradaile, J.E. Schaffer, Lipotoxicity in the heart, Curr. Hypertens. Rep. 7 (2005) 412-417.

[53] H.C. Chiu, A. Kovacs, R.M. Blanton, X. Han, M. Courtois, C.J. Weinheimer, K.A. Yamada, S. Brunet, H. Xu, J.M. Nerbonne, M.J. Welch, N.M. Fettig, T.L. Sharp, N. Sambandam, K.M. Olson, D.S. Ory, J.E. Schaffer, Transgenic expression of fatty acid transport protein 1 in the heart causes lipotoxic cardiomyopathy, Circ. Res. 96 (2005) 225-233

[54] Y.T. Zhou, P. Grayburn, A. Karim, M. Shimabukuro, M. Higa, D. Baetens, L. Orci, R.H. Unger, Lipotoxic heart disease in obese rats: implications for human obesity, Proc. Natl. Acad. Sci. U. S. A. 97 (2000) 1784-1789.

[55] V. Bezaire, L.L. Spriet, S. Campbell, N. Sabet, M. Gerrits, A. Bonen, M.E. Harper, Constitutive UCP3 overexpression at physiological levels increases mouse skeletal muscle capacity for fatty acid transport and oxidation, FASEB J. 19 (2005) 977-979.

[56] J. Buchanan, P.K. Mazumder, P. Hu, G. Chakrabarti, M.W. Roberts, U.J. Yun, R.C. Cooksey, S.E. Litwin, E.D. Abel, Reduced cardiac efficiency and altered substrate metabolism precedes the onset of hyperglycemia and contractile dysfunction in two mouse models of insulin resistance and obesity, Endocrinology 146 (2005) $5341-5349$.

[57] U. De Marchi, C. Castelbou, N. Demaurex, Uncoupling protein 3 (UCP3) modulates the activity of Sarco/endoplasmic reticulum $\mathrm{Ca}^{2+}$-ATPase (SERCA) by decreasing mitochondrial ATP production, J. Biol. Chem. 286 (2011) 32533-32541.

[58] E. Haugen, J. Chen, J. Wikstrom, J. Gronros, L.M. Gan, L.X. Fu, Parallel gene expressions of IL-6 and BNP during cardiac hypertrophy complicated with diastolic dysfunction in spontaneously hypertensive rats, Int. J. Cardiol. 115 (2007) 24-28.

[59] A.J. Gilde, K.A. van der Lee, P.H. Willemsen, G. Chinetti, F.R. van der Leij, G.J. van der Vusse, B. Staels, M. van Bilsen, Peroxisome proliferator-activated receptor (PPAR) alpha and PPARbeta/delta, but not PPARgamma, modulate the expression of genes involved in cardiac lipid metabolism, Circ. Res. 92 (2003) 518-524.

[60] D.M. Muoio, P.S. MacLean, D.B. Lang, S. Li, J.A. Houmard, J.M. Way, D.A. Winegar, J.C. Corton, G.L. Dohm, W.E. Kraus, Fatty acid homeostasis and induction of lipid regulatory genes in skeletal muscles of peroxisome proliferator-activated receptor (PPAR) alpha knock-out mice. Evidence for compensatory regulation by PPAR delta, J. Biol. Chem. 277 (2002) 26089-26097.

[61] H.T. Tseng, Y.J. Park, Y.K. Lee, D.D. Moore, The orphan nuclear receptor small heterodimer partner is required for thiazolidinedione effects in leptin-deficient mice, J. Biomed. Sci. 22 (2015) 30.

[62] B. Renga, A. Mencarelli, M. Migliorati, S. Cipriani, C. D'Amore, E. Distrutti, S. Fiorucci, SHP-dependent and -independent induction of peroxisome proliferator-activated receptor-gamma by the bile acid sensor farnesoid $\mathrm{X}$ receptor counter-regulates the pro-inflammatory phenotype of liver myofibroblasts, Inflamm. Res. 60 (2011) 577-587.

[63] S.C. Kim, C.K. Kim, D. Axe, A. Cook, M. Lee, T. Li, N. Smallwood, J.Y. Chiang, J.P. Hardwick, D.D. Moore, Y.K. Lee, All-trans-retinoic acid ameliorates hepatic steatosis in mice by a novel transcriptional cascade, Hepatology 59 (2014) 1750-1760.

[64] H. Nishizawa, K. Yamagata, I. Shimomura, M. Takahashi, H. Kuriyama, K. Kishida, K. Hotta, H. Nagaretani, N. Maeda, M. Matsuda, S. Kihara, T. Nakamura, H. Nishigori, H. Tomura, D.D. Moore, J. Takeda, T. Funahashi, Y. Matsuzawa, Small heterodimer partner, an orphan nuclear receptor, augments peroxisome proliferator-activated receptor gamma transactivation, J. Biol. Chem. 277 (2002) 1586-1592.

[65] A. Kassam, J.P. Capone, R.A. Rachubinski, The short heterodimer partner receptor differentially modulates peroxisome proliferator-activated receptor alpha-mediated transcription from the peroxisome proliferator-response elements of the genes encoding the peroxisomal beta-oxidation enzymes acyl-CoA oxidase and hydratase-dehydrogenase, Mol. Cell. Endocrinol. 176 (2001) 49-56. 